\title{
A BLACK DAY AT WASCANA MARSH, REGINA
}

ROBERT KREBA, Saskatchewan Museum of Natural History, Regina, Saskatchewan, S4P $3 \vee 7$.

A phone call from Fred Lahrman on 6 November 1978 presaged one of the blackest days in the history of Regina's Wascana Marsh. Fred and Lorne Scott had just seen a fullplumaged male Black Scoter near the waterfowl display ponds at the marsh. As an added bonus, he said that a male Black Duck was also present.

When I arrived about half an hour later, at 1400, Fred and Lorne were photographing the scoter. What I saw was a jet-black duck with its head under its wing, dozing in the water about 20 yards from shore. While this was certainly a Black Scoter, the sight was somewhat less than stimulating.

Fred informed me that they hadn't seen the Black Duck since returning from the Museum with his camera equipment. Just as they were readying themselves to go, Bob Luterbach drove up. He had been alerted earlier by Lahrman. Bob and I scrutinized the uncooperative scoter. After several minutes of this, we determined to separate and track down the missing Black Duck.

A few minutes later, Bob was back. He wouldn't tell me what he had found though. He set up his scope on the car window mount and focused it on the far side of the marsh. "Now, look and tell me what you see". I looked, but all I could see were geese, Canada Geese, with nary a rare duck among them. But wait, what was that smallish dark form floating placidly in their midst? "It's a Brant!" I exclaimed.
The next question was, what kind of Brant? We looked carefully, but could not decide, as the key fieldmark - the belly - was below the waterline. Bob went to phone Lahrman.

In the meantime, the Brant obligingly left the water to stand on the ice with a group of resting Canada's. This enabled us to at once identify it as an adult "Black" Brant, the western race, formerly regarded as a species separate from the lightbellied eastern race of Brant. Fred came and was able to photograph the Brant in spite of the distance and poor light conditions.

Margaret Belcher arrived with Elizabeth Cruickshank at about 1500. She had independently discovered the Black Scoter earlier and had returned to show it to Mrs. Cruickshank. The scoter put on a better show at this point, revealing his black head and bill with its bright yellow knob. The plumage was jetblack, as were the feet and eyes. The bird held its tail cocked up and resembled some unlikely relative of a Ruddy Duck more than anything else.

In all this excitement, the Black Duck was all but forgotten. We made a few half-hearted surveys of the marsh for it, but it was not to be found. Bob and I then left. At 1600 , Fred Lahrman saw the Brant fly off with a flock of Canada's, going out to feed in the grain-fields southeast of the city. He drove out and scanned the feeding flocks, but was unable to find it there. 
An intense weather system of the preceding two days was certainly the source of both the scoter and the Brant. Very strong west to northwest winds blew in on 4 November with winds gusting up to $110 \mathrm{~km} / \mathrm{hr}$. through the night and most of the 5th. Fred G. Bard, in personal communication with Fred Lahrman, reported similar winds from the west to northwest while travelling west to Surrey, British Columbia, from Calgary, Alberta. These were even stronger, gusting up to $120 \mathrm{~km} / \mathrm{hr}$. Whether or not this system was responsible for the Black Duck is uncertain. The few Regina area sightings of recent years have been at this time, late in the fall, so it is likely that the Black Duck's presence was coincidental.

The Brant was the first recorded at Regina and is only the ninth record for Saskatchewan. Sightings are mostly of one to three birds, though flocks of as many as eight and 18 have been reported. ${ }^{14}$ Fred Lahrman saw another Brant 11 April 1980 at Tregarva slough swimming in the midst of a flock of $1000+$ Whitefronted and Canada Geese. Previous sightings have been summarized by Dzubin and Hook $^{3}$ and Belcher. ${ }^{2}$

The Black Scoter was the second Regina record, the first being a female and an immature, seen at the Condie Nature Refuge, northwest of the city, on 16-18 October 1976. ${ }^{2}$ These birds were photographed by Lahrman and constituted the first confirmed record for the province. Previous sightings were: 24 October 1970, a female or immature at Tobin Lake, and 31 October 1970, a female or immature on the Saskatchewan River, north of Nipawin, both sighted by S. D. Riome. ${ }^{6}$ On 14 October, three scoters, and 15 October 1975 , two scoters were seen at Blackstrap Lake by A. R. Smith. ${ }^{5}$ More recently, a probable adult female Black Scoter was sighted on Wascana Lake, Regina, on 23 and 26 October 1979, by $B$. Luterbach and several others.

The Black Scoter was not found on 7 November despite intensive searching by many observers. We did manage to find the Black Duck, at last, as well as a beautifully plumaged male Hooded Merganser.

At noon, we all left for lunch, with the exception of Bob Luterbach, who was rewarded by the reappearance of the Brant at about 1245. It flew in with a flock of Canada Geese, returning from foraging for waste grain in the fields. For most of the afternoon, the Brant was admired by a large group of Regina birders, as well as a few passersby who were attracted by the unusual crowd of people bristling with binoculars and telescopes. The Brant was most cooperative, affording much closer views under ideal conditions, as well as a series of colour slides. The Brant was not seen after the 7 th.

${ }^{1}$ ARMSTRONG, F. B. 1974. Brant at Carrot River. Blue Jay 32(4):250.

${ }^{2}$ BELCHER, M. 1980. Birds of Regina. Sask. Natur. Hist. Soc. Spec. Publ. 12, Regina, Saskatchewan.

${ }^{3}$ DZUBIN, A., and N. HOOK. 1966. Black Brant records from western Saskatchewan. Blue Jay 24(3):124-126.

${ }^{4}$ HARRIS, W. C. 1976. in E. M. Serr, Northern Great Plains Region, Am. Birds 30(1):87.

${ }^{5}$ O'NEIL, P. 1975. Fall migration, Saskatoon Field Notes, No. 17.

${ }^{6}$ RIOME, S. D. 1971. Sight records of the common Scoter in Saskatchewan. Blue Jay 29(1):31-32. 